\begin{abstract}
Boston
A new Center for Islet Cell Transplantation has been created at Harvard Medical School with $\$ 20$ million funding over the next five years from the Juvenile Diabetes Foundation (JDF). Research at the center will focus on finding a cure for Type 1 diabetes through islet cell transplantation without the need for long-term immunosuppression.

In an announcement last month, the two groups promised that the center will house an "unprecedented combination of experts in diabetes and many other scientific fields." The center will employ 32 researchers, many of whom are said not to have worked on diabetes previously. They will focus on four main research areas outlined by a JDF task force last year: autoimmunity, islet transplantation, tolerance induction, and expansion of islet cell supply either from tissue culture or xenotransplants.
\end{abstract}

\section{Madrid}

On September 8th, the Spanish National Research Council (CSIC) announced that it would merge its biomedical research activities with the Autonomous University of Madrid (UAM) to create a new institute called Alberto Sols. The center will be located on the UAM School of Medicine campus and linked with Hospital de La Paz.

According to the center's director, Juan Bernal, Alberto Sols will operate on an annual budget of US\$14 million-US\$8 million from UAM and the remainder from CSIC's Biomedical Institute and research contracts with private institutions. The only other institute in Spain with this level of funding is the National Center for Cancer Research, "Carlos III," headed by Mariano Barbacid. Spain spends less than two percent of its gross national product on $R \& D$.

Alberto Sols will employ 52 associate professors and 150 research fellows. Programs will focus on cancer biology, mole cular genetics, mitochondrial disorders and development and aging at microgravity conditions.

\section{Edinburgh}

The Scottish Office and the Scottish Higher Education Funding Council are to fund a new $£ 38$ million (US\$ 63 million) medical school at the University of Edinburgh. Building is expected to be finished in 2002 and the school will house 450 students, including research postgraduates.

Theschool will belinked to a new Edinburgh Royal Infirmary to be built by a consortium of British construction companies and a bank. However, the private venture-estimated cost $f 180$ millionhas been criticized by the British Medical Association for its high costs and design.

Karen Birmingham, New York \& Xavier Bosch, Barcelona

\title{
Skepticism surrounds Australia's biomedical research revolution
}

The last two months witnessed a profusion of announcements in Australia heral ding a major push for the country to become a significant contender in the field of biomedical research. But somescientists are doubtful that the proposals will be implemented quickly enough to achieve this goal. At a national science briefing in Canberra, former Australian Academy of Science president Sir Gustav Nossal stressed that government and industry must band together to create a climate for research-based technology. "There is still time for Australia to catch the bus, but only just," said Nossal.

Last month, the Commonwealth Scientific and Industrial Research Organisation (CSIRO) announced that it will join the University of Queensland in building a new world-class biomedical research facility in Brisbane. CSIRO's contribution will increase funding for the project to AUS\$80 million (US\$44 million). The Biological Sciences Institute will employ 850 researchers working in genomics, developmental, cellular and structural biology, molecular design and bioinformatics. (Nature, 394, 7; 1998).

This is coupled with plans for a new cancer research center at the Queensland Institute of Medical Research, backed by the state government. Director Lawrie Powell predicts the new center will eventually be on a par with Stanford University, California. “There's nothing quite like this in the southern hemisphere because it will be a comprehensive cancer center covering the spectrum of basic science research through to new treatments and clinical trials," says Powell. It is hoped that Australian pharmaceutical companies, which currently pay big dollars to have compounds tested overseas, will be able to take advantage of the new facilities by 2001.

But although some scientists obviously stand to make major gains if the new plans are successfully implemented, lobby groupssuch astheAustralian Society

for Medical Research (ASMR) and the Federation of Australian Scientific and Technological Societies (FASTS), are skeptical as to how much impact these ventures will have for Australian biomedical $R \& D$ as a whole.

ASM R president Steven Wesselingh questions whether top scientists will be recruited to either of the antipodean sitesin

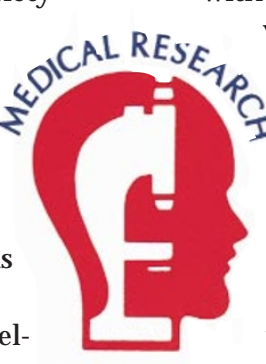

BRINGING HEALTH TO LIFE overtaken and lose any commercial edge [these new programs might bring]," he adds.

FASTS president Peter Cullen agrees that if government funding is not increased, "the best and most capable" of Australia's medical researchers will continueto move abroad to carry out their work "where they can properly be supported."

The ASMR, which represents 15,000 researchers, is al so cynical about last month's government announcement to establish a Biotechnology Task Force charged

with developing strategies for access to venture capital, protection of biodiversity and management of intellectual property. According to Wesselingh, the as-yet unfunded taskforceislikely to be a mere "talkfest."

The ASMR is pushing for a reinstatement of the 150 percent tax concession for R\&D investment, which was reduced to 125 percent two years ago-a reduction blamed for the first drop in the face of greater financial incentives for research overseas. Rather than filling new posts "we can expect a brain drain," warns Wesselingh, who points out that the Australian research budget of $\$ 170$ million is minisculein comparison with the $\$ 13$ bilIion of the US National Institutes of Health. "Without some imagination in research funding we could be quickly
$R \& D$ expenditure in 11 years ( $N$ ature 394, 512; 1998), and insists that to achievethis, biomedical research needs to become an issue for the electorate. In fact, the opposition Labor party has seized on this opportunity and promised to restore the concession for industrial $R \& D$ if elected on October 3rd.

\section{Rada Rouse, Brisbane}

